Original paper

DOI: 10.2478/agri-2021-0003

\title{
IMPROVING RESISTANCE OF FOENICULUM VULGARE TO WATER DEFICIT STRESS BY NATURAL REGULATORS
}

\author{
FARSHAD SORKHI $^{1 * \dagger}$, RAMIN ROSTAMI ${ }^{1}$, KAZEM GHASSEMI-GOLEZANI ${ }^{2}$ \\ ${ }^{1}$ Islamic Azad University, Miandoab, Iran \\ ${ }^{2}$ University of Tabriz, Tabriz, Iran
}

Sorkhi, F., Rostami, R. and Ghassemi-Golezani, K. (2021). Improving resistance of Foeniculum vulgare to water deficit stress by natural regulators. Agriculture (Polnohospodárstvo), 67(1), 29-41.

\begin{abstract}
This research was conducted as a combined analysis with four replications in two years (2018-2019). Treatments were irrigation up to $90 \%, 50 \%$, and $20 \%$ field capacity (as normal irrigation, moderate and severe water deficit stresses, respectively) and foliar application of natural regulators (untreated as control, salicylic acid, spermidine, and methanol). Increasing water deficit stress was led to a significant increase in essential oil percentage and proline content and a significant decrease in yield parameters and seed yield. Most of the traits (except the percentage of essential oil) were affected by natural growth regulators. The highest seed yield $(1,127.59 \mathrm{~kg} / \mathrm{ha})$, plant biomass $(5,426.92 \mathrm{~kg} / \mathrm{ha})$, essential oil yield $(22.67 \mathrm{~kg} / \mathrm{ha})$, and proline content $(29.34 \mu \mathrm{mol} / \mathrm{g}$ fresh weight) were obtained in methanol treated plants under normal irrigation. However, the highest amount of these traits under moderate and severe water deficit was recorded for salicylic acid-treated plants. Therefore, foliar spray of methanol was a useful treatment for non-stress conditions, but, application of salicylic acid was the superior treatment for reducing the negative effects of water deficit stress on Foeniculum vulgare.
\end{abstract}

Key words: essential oil, fennel, salicylic acid, stress, yield

Fennel (Foeniculum vulgare) is one of the most important medicinal plants of the Apiaceae family (Ibrahim et al. 2020). Fennel essential oil is used in many industries such as pharmaceutical, food, cosmetic, and health (Pouryousef 2014). The amount of essential oil produced in medicinal plants is affected by environmental stresses such as water deficit (Tatrai et al. 2016). Water deficit causes the production of reactive oxygen species (ROS) in plants and consequently the reactive oxygen species damages biomolecules such as lipids, proteins, and nucleic acids (Tardieu et al. 2018). Some of the detrimental impacts of water shortage on plants may be alleviated by foliar application of natural products such as salicylic acid, spermidine, and methanol (Hossinzadeh et al. 2015; Ghilavizadeh et al. 2019).

Salicylic acid or ortho-hydroxybenzoic acid belongs to the group of phenolic compounds (Mabrouk et al. 2019), that induce drought tolerance in plants (Roghayyeh et al. 2014), and is considered as a plant hormone (Seagate et al. 2020). In the study of seed pre-treatment with salicylic acid, the negative effects of water deficit stress on seed yield, yield components, and the amount of fennel essential oil were reduced due to the application of this growth regulator in stress-free conditions, but it had no significant effect on seed yield (Rizwan et al. 2020). Najmeh et al. (2015) stated that foliar application

Farshad Sorkhi (*Corresponding author), Department of Agronomy and Plant Breeding, Miandoab Branch, Islamic Azad University, Miandoab, Iran. E-mail: farsorkh@gmail.com

Ramin Rostami, Miandoab Branch, Islamic Azad University, Miandoab, Iran. E-mail: Probe.p@yahoo.com

Kazem Ghassemi-Golezani, Department of Plant Ecophysiology, University of Tabriz, Iran. E-mail: golezani@gmail.com

(C) 2021 Authors. This is an open access article licensed under the Creative Commons Attribution-NonComercial-NoDerivs License

(http://creativecommons.org/licenses/by-nc-nd/4.0/). 
of salicylic acid under drought stress increased the yield of Nigella sativa by $79.05 \%$ and $10 \mu \mathrm{M}$ salicylic acid under moderate stress increased the essential oil content by $150 \%$.

Antioxidant and anti-ethylene compounds help plants to maintain membranes and their physiological function under drought stress (Li et al. 2015). Polyamines, including spermidine, inhibit ethylene production (Kang et al. 2013). The results of Shakib et al. (2013) showed the beneficial effects of foliar application of spermidine on flowering and vegetative characteristics of Cyclamen persicum. The application of spermidine in the concentration $0.2 \mathrm{mM}$ improved the flowering period, flower life, and increased the number of flowers, while the $0.4 \mathrm{mM}$ concentration improved some vegetative characteristics such as the number of leaves. Niakan et al. (2011) reported that foliar application of spermidine under salt stress significantly decreased the inhibitory effects of salinity on germination percentage, root length, shoot length, fresh weights, and dry weight, and also the content of osmotic regulators in wheat seedlings. Some reports have suggested that salicylic acid plays a much more successful role than spermidine in controlling the effects of water deficit (Rizwan et al. 2020; Seagate et al. 2020). Some studies have shown that methanol application on most crops decreases photorespiration, and increases water use efficiency, leaf area, and ultimately yield (Dorokhov et al. 2015). Research on the effect of foliar application of methanol under water deficit stress revealed that biomass of plants increases this treatment (Mirakhori et al. 2009; Moghadas et al. 2013). According to research such as salicylic acid in Triticum aestivum (Seagate et al. 2020), Nigella sativa (Najmeh et al. 2015), and Foeniculum vulgare (Ghilavizadeh et al. 2019), methanol in Cicer arietinum (Hossinzadeh et al. 2015) and spermidine in Cuminum cyminum (Bakhtati et al. 2016) growth regulators cause resistance to drought stress and significantly increase crop growth and yield. Iran is located in an arid and semi-arid region, where prevention or reduction of damages on plants due to water deficit is very important. So, this research was conducted to evaluate the effects of salicylic acid, methanol, and spermidine on Foeniculum vulgare under different levels of water supply.

\section{MATERIAL AND METHODS}

This research was conducted as a combined analysis with four replications in two years (2018-2019) in the Research Farm of Miandoab Branch of Azad University, Iran. The climate of Iran is arid and semi-arid. The geographical coordinates of Miandoab city include longitude with 48 degrees and 52 minutes east and latitude with 35 degrees and 20 minutes north. The altitude of the region is 1,300 meters above sea level. The climatic conditions of the region during the experiment at the study site are presented in Table 1. Treatments were irrigation up to $90 \%, 50 \%$, and $20 \%$ field capacity (as normal irrigation, moderate and severe stresses, respectively)

$\mathrm{T}$ a

Climate of the region during the experiment

\begin{tabular}{|c|c|c|c|c|c|c|c|c|c|}
\hline \multirow[b]{2}{*}{ Month } & \multicolumn{4}{|c|}{2018} & \multirow[b]{2}{*}{ Month } & \multicolumn{4}{|c|}{2019} \\
\hline & $\begin{array}{c}\text { Minimum } \\
\text { temperature } \\
{\left[{ }^{\circ} \mathrm{C}\right]}\end{array}$ & $\begin{array}{c}\text { Maximum } \\
\text { temperature } \\
{\left[{ }^{\circ} \mathrm{C}\right]}\end{array}$ & $\begin{array}{c}\text { Rainfall } \\
{[\mathrm{Mm}]}\end{array}$ & $\begin{array}{c}\text { Relative } \\
\text { humidity } \\
{[\%]}\end{array}$ & & $\begin{array}{c}\text { Minimum } \\
\text { temperature } \\
{\left[{ }^{\circ} \mathrm{C}\right]}\end{array}$ & $\begin{array}{c}\text { Maximum } \\
\text { temperature } \\
{\left[{ }^{\circ} \mathrm{C}\right]}\end{array}$ & $\begin{array}{c}\text { Rainfall } \\
\text { [Mm] }\end{array}$ & $\begin{array}{c}\text { Relative } \\
\text { humidity } \\
{[\%]}\end{array}$ \\
\hline April & 3.6 & 13.1 & 25.9 & 49 & April & 4.0 & 18.4 & 24.7 & 46 \\
\hline May & 8.1 & 18.7 & 26.6 & 47 & May & 8.9 & 24.5 & 37.8 & 52 \\
\hline June & 11.4 & 25.6 & 20.6 & 42 & June & 12.7 & 30.8 & 29.7 & 46 \\
\hline July & 15.3 & 28.1 & 16.7 & 41 & July & 16.6 & 34.4 & 12.7 & 37 \\
\hline August & 16.8 & 29.7 & 7.9 & 33 & August & 18.4 & 36.8 & 4.2 & 30 \\
\hline September & 14.3 & 26.7 & 11.4 & 36 & September & 16.7 & 33.8 & 9.6 & 32 \\
\hline
\end{tabular}


and foliar application of natural regulators included untreated as control, salicylic acid at a concentration of $1 \mathrm{mM}$ (Chen et al. 2016), spermidine with the concentration of $0.2 \mathrm{mM}$ (Li et al. 2015) and methanol with the concentration of $30 \%$ by volume (Zheng et al. 2008). To determine the soil moisture and irrigation time in each test plot, a tensiometer model 2710ARL made in the USA was installed in the depth of $15 \mathrm{~cm}$. Irrigation was performed whenever the humidity reached the desired level for irrigation (in the present study, the amount of soil water potential with -0.3 bar equivalent to field capacity, -1.47 bar equivalent to $90 \%$ of field capacity, -7.35 bar equivalent to $50 \%$ of field capacity, -11.76 bar equivalent to $20 \%$ of field capacity, and -15 bar equivalent to permanent wilting of the plant). The physical and chemical characteristics of the soil at the study site are presented in Table 2 .

The physical and chemical properties of soil were determined by conventional laboratory methods. In order to measure soil samples $\mathrm{pH}$, in suspension with a ratio of 2 to 1 solution to soil was used (Thomas 1996). Electrical conductivity was measured in filtered extracts with a ratio of 2 to 1 solution to soil (Rhoades 1996). By titration recurrence method, soil calcium carbonate was measured with one normal hydrochloric acid (Loeppert \& Sparks 1996). By wet oxidation method, the percentage of soil organic carbon was measured (Nelson \& Sommers 1996). By the hydrometric method, soil texture was measured (Gee \& Bauder 1986). By digestion method with nitric acid and perchloric acid, soil phosphorus was measured too (Kuo 1996).

In both years after plowing the land in March, the land was levelled and plotted. The size of each plot was $3 \times 4$ square meters. In each plot, 6 planting rows were created with a distance of $50 \mathrm{~cm}$ from each other. Fennel seeds were planted $15 \mathrm{~cm}$ apart on rows with a depth of 2 to $3 \mathrm{~cm}$. Planting was done in April and irrigation was done immediately after planting. When the plants reached a height of $5 \mathrm{~cm}$, the field was thinned to obtain the proper density.

\section{Proline content}

The amount of plant proline in the $75 \%$ flowering stage was measured by Bates et al. (1973) method and was reported based on micromol of proline per gram of fresh leaf $(\mu \mathrm{mol} / \mathrm{g} \mathrm{FW})$.

\section{Yield and yield components}

After harvesting in the second half of September, 7 plants were randomly selected and then measured plant height, number of branches per plant, number of umbels per plant, number of seeds per umbel, and weight of one thousand seeds. To determine the yield in each plot, two side rows and a half meter from the first and a half meter from the end of the plot were removed, biological yield and seed yield were determined at the level of 6 square meters.

\section{Harvest index}

The following equation was used to calculate the harvest index (Ntanos \& Koutroubas 2002).

$$
\mathrm{HI}=(\mathrm{SY} / \mathrm{BY}) \times 100
$$

HI - Harvest index (percentage); SY - Seed yield $[\mathrm{kg} / \mathrm{ha}]$ and BY - Biological yield [kg/ha].

\section{Essential oil}

The amount of $50 \mathrm{~g}$ of seeds produced in each plot was randomly selected. First, the seeds were thoroughly ground, then poured into a 1-liter balloon and $750 \mathrm{ml}$ of water was added to it. Then, the solution was placed in a clevenger apparatus for 4 hours. After dehumidification, essential oil percent was determined by sodium sulfate using the Telci method (Telci et al. 2009). Essential oil yield was

$$
\mathrm{T} \text { a }
$$

Physical and chemical properties of soil

\begin{tabular}{|c|c|c|c|c|c|c|c|c|c|}
\hline Soil Texture & $\begin{array}{c}\text { Silt } \\
{[\%]}\end{array}$ & $\begin{array}{c}\text { Clay } \\
{[\%]}\end{array}$ & $\begin{array}{c}\text { Sand } \\
{[\%]}\end{array}$ & $\begin{array}{c}\text { Total N } \\
{[\%]}\end{array}$ & $\begin{array}{c}\mathrm{K} \\
{[\mathrm{mg} / \mathrm{kg}]}\end{array}$ & $\begin{array}{c}\mathrm{P} \\
{[\mathrm{mg} / \mathrm{kg}]}\end{array}$ & $\begin{array}{c}\text { OC } \\
{[\%]}\end{array}$ & $\begin{array}{c}\mathrm{EC} \\
{[\mathrm{dS} / \mathrm{m}]}\end{array}$ & $\mathrm{pH}$ \\
\hline Silty loam & 57.7 & 21.8 & 20.5 & 0.08 & 264.17 & 20.25 & 0.83 & 1.29 & 7.19 \\
\hline
\end{tabular}

$\mathrm{OC}$ - organic carbon; EC - electrical conductivity of soil solution 
calculated by multiplying seed yield by the percentage of essential oil (Stefanini et al. 2006).

SAS software was used for statistical analysis of data and Excel software was used to draw graphs. The means were compared with Duncan's multiple range test at a $5 \%$ probability level.

\section{RESULTS AND DISCUSSION}

\section{Plant height}

Plant height at the level of one percent probability was affected by the simple effects of water deficit stress and natural regulators, but the interaction of these two treatments had no significant effect on plant height (Table 3). The highest plant height of the fennel was observed non-water deficit stress treatment (irrigation $90 \%$ of field capacity) with $86.14 \mathrm{~cm}$.

Under the influence of moderate and severe water deficit stresses, plant height decreased by $25.04 \%$ $(64.57 \mathrm{~cm})$ and $45.17 \%(47.23 \mathrm{~cm})$ compared to the non-stress treatment $(86.14 \mathrm{~cm})$, respectively (Table 4). The first noticeable effect of water deficit stress on the plant is to reduce plant height (Sah et al. 2014). Plant height is greatly affected by genetic characteristics (Ahamadizadeh et al. 2012). However, environmental conditions such as water deficit stress significantly affect plant height (Tatrai et al. 2016). According to research results, water shortage reduces the turgor pressure of stomatal guard cells, stomatal conduction, growth rate, photosynthesis rate and as a result, morphological characteristics are reduced such as plant height (Najmeh et al. 2015; Liu et al. 2017). Plant growth is associated with an increase in cell size and this is the most sensitive process in plants to water deficit stress (Seagate et al. 2020). In conditions without water stress, increasing growth and leaf area has a direct effect on increasing the absorption of solar energy and leads to an increase in plant height (Shakib et al. 2013). The reduction of water during plant growth and development has a negative effect on plant growth parameters (Rizwan et al. 2020). Askari and Ehsanzadeh (2015) reported that irrigation at the time of the evacuation of $75 \%$ and $85 \%$ of soil moisture, led to a reduction of $20 \%$ and $31 \%$ in height of fennel plant compared to irrigation at the time of the evac- uation $35 \%$ of soil moisture. Kouchaki et al. (2006) showed that with increasing the irrigation period from 10 to 20 and 30 days, the height of the fennel plant decreased significantly. It has been found that drought stress reduces plant height by reducing plant growth rate (Liu et al. 2017). Foliar application of methanol and salicylic acid significantly increased plant height compared to control and spermidine. This increase in plant height was $11.67 \%(68.02 \mathrm{~cm})$ with methanol foliar application and 22.06\% (74.35 $\mathrm{cm})$ with salicylic acid foliar application compared to the control treatment $(60.91 \mathrm{~cm})$ (Table 4$)$. About $90 \%$ of the dry weight of plants is due to the assimilation of $\mathrm{CO}_{2}$ by photosynthesis and increasing the rate of photosynthesis is useful to increase the production capacity of crops (Tatrai et al. 2016). Plants can easily absorb methanol foliar application and use it as a carbon source (Tardieu et al. 2018). Salehi (2013) confirmed that methanol foliar application significantly increased bean plant height. Ahmadian et al (2011) showed that spermidine increased the height of Matricaria chamomilla, but this increase was statistically lower compared to salicylic acid.

Salarpour and Frahbakhash (2014) reported that increasing the levels of salicylic acid from zero to one $\mathrm{mM}$, significantly increased the height of the fennel plant. They stated that salicylic acid increases cell division in the plant meristem and thus increases plant height. The results of another study showed that salicylic acid improves photosynthesis and plant growth by increasing the activity of the rubisco enzyme (Seagate et al. 2020). Salicylic acid seems to regulate various physiological processes such as plant growth and development through the synthesis of special proteins called protein kinases, which are responsible for regulating cell division, differentiation, morphogenesis and play an effective role in increasing plant height.

\section{Yield components}

All traits related to yield components including the number of branches per plant, number of umbels per plant, number of seeds per umbel, and weight of one thousand seeds were significantly affected by the interaction water deficit stress, and natural regulators (Table 3).

Investigation of the interaction effects of water deficit stress with natural regulators showed that 
under control treatment (irrigation at $90 \%$ of field capacity) compared to moderate and severe water deficit stress treatments in methanol foliar application had the highest number of branches and with increasing water deficit stress, the amount of this trait in all foliar applications decreased significantly. The results showed that in the lack of water deficit stress, methanol foliar application had the highest number of branches (15.28) and increased the amount of this trait in the fennel by $8.44 \%$ compared to the control (non-foliar application) treatment with 14.09 number (Table 5).

The use of salicylic acid in moderate water deficit stress ( $50 \%$ of field capacity) increased the number of branches by $47.08 \%$ (12.09) compared to control (non-foliar application) with 8.22 num-

$\mathrm{T}$ a b 1 e 3

Analysis of variance of evaluated traits in Foeniculum vulgare

\begin{tabular}{|c|c|c|c|c|c|c|c|}
\hline S.O.V & $\mathrm{df}$ & Plant height & $\begin{array}{c}\text { Number of } \\
\text { branches per } \\
\text { plant }\end{array}$ & $\begin{array}{c}\text { Number of } \\
\text { umbels per } \\
\text { plant }\end{array}$ & $\begin{array}{c}\text { Number of } \\
\text { seeds per } \\
\text { umbel }\end{array}$ & $\begin{array}{c}\text { Weight of } \\
\text { one thousand } \\
\text { seeds }\end{array}$ & $\begin{array}{l}\text { Biological } \\
\text { yield }\end{array}$ \\
\hline Year & 1 & 9.24 & 5.34 & 13.86 & 2.28 & 1.06 & 114.60 \\
\hline Year $\times$ Replication & 6 & 29.60 & 7.82 & 10.45 & 21.70 & 3.11 & 125.21 \\
\hline $\begin{array}{l}\text { Water deficit stress } \\
\text { (WDS) }\end{array}$ & 2 & $183.75^{* *}$ & $16.51 *$ & $23.79 *$ & $68.47 * *$ & $13.70 * *$ & $661.74 * *$ \\
\hline Year $\times$ WDS & 2 & 13.99 & 2.93 & 6.22 & 9.16 & 3.52 & 70.59 \\
\hline $\begin{array}{l}\text { Natural regulators } \\
\text { (NR) }\end{array}$ & 3 & $192.67 * *$ & $14.04 *$ & $17.34 *$ & $88.42 * *$ & $19.07 * *$ & $397.35^{*}$ \\
\hline Year $\times N R$ & 3 & 10.86 & 1.38 & 7.92 & 3.04 & 4.18 & 68.39 \\
\hline WDS $\times N R$ & 6 & 3.50 & $11.97 *$ & $34.80 * *$ & $29.94 *$ & $16.25 * *$ & $278.46^{*}$ \\
\hline Year $\times$ WSD $\times$ NR & 6 & 12.32 & 5.81 & 6.56 & 7.53 & 2.78 & 75.06 \\
\hline Error & 66 & 15.95 & 4.37 & 5.02 & 11.93 & 2.27 & 106.53 \\
\hline $\mathrm{CV}$ & & 11.38 & 6.52 & 9.13 & 7.95 & 2.63 & 12.71 \\
\hline
\end{tabular}

Table 3 - continue

\begin{tabular}{|c|c|c|c|c|c|c|}
\hline S.O.V & df & Seed yield & Harvest index & $\begin{array}{l}\text { Essential oil } \\
\text { percent }\end{array}$ & $\begin{array}{l}\text { Essential oil } \\
\text { yield }\end{array}$ & Proline content \\
\hline Year & 1 & 95.32 & 5.83 & 0.28 & 0.76 & 4.25 \\
\hline Year $\times$ Replication & 6 & 93.17 & 7.95 & 0.17 & 0.82 & 9.21 \\
\hline $\begin{array}{l}\text { Water deficit stress } \\
\text { (WDS) }\end{array}$ & 2 & $276.51 * *$ & $16.27 *$ & $0.83 * *$ & $11.49 *$ & $25.47 *$ \\
\hline Year $\times$ WDS & 2 & 26.33 & 4.58 & 0.07 & 2.80 & 9.17 \\
\hline $\begin{array}{l}\text { Natural regulators } \\
\text { (NR) }\end{array}$ & 3 & $250.24 * *$ & $15.91 *$ & 0.23 & $8.75^{*}$ & $20.93 *$ \\
\hline Year $\times$ NR & 3 & 54.32 & 2.02 & 0.04 & 3.14 & 8.33 \\
\hline WDS $\times$ NR & 6 & $315.17 * *$ & 5.34 & 0.03 & $7.39 *$ & $23.44 * *$ \\
\hline Year $\times W S D \times N R$ & 6 & 14.49 & 1.68 & 0.11 & 2.69 & 7.75 \\
\hline Error & 66 & 48.78 & 4.10 & 0.13 & 2.91 & 6.47 \\
\hline $\mathrm{CV}$ & & 9.23 & 6.36 & 2.72 & 5.14 & 8.96 \\
\hline
\end{tabular}

* and ** - significant difference $P \leq 0.05$ and significant difference $P \leq 0.01$, respectively (S.O.V: Sources of variation) Note: $\mathrm{df}$ - degrees of freedom; $\mathrm{CV}$ - coefficient of variation 
ber and in severe water deficit stress $(25 \%$ of field capacity) increased number of branches by $90.45 \%$ (8.18) compared to control (non-foliar application) with 4.61 number (Table 5). The highest number of umbels per plant (29.67) was observed in non-stress conditions in methanol foliar application which was $18.53 \%$ higher than the control (non-foliar application) treatment. In moderate and severe stress treatments, salicylic acid was able to increase the number of umbels per plant compared to the control treatment by $21.96 \%$ (23.04 number) and $73.14 \%$ (17.54 number), respectively (Table 5). With increasing water deficit stress, the number of seeds per umbel decreased in all foliar application treatments. The highest number of seeds per umbel with 245.60 was observed to methanol foliar application in nonstress conditions (irrigation at $90 \%$ of field capacity) and the lowest belonged to control treatment in severe stress (irrigation at $20 \%$ of field capacity). In moderate water deficit stress, foliar application with salicylic acid increased the number of seeds per umbel by $48.86 \%$ ( 186.31 number) compared to control (125.15 number). In severe water deficit stress, foliar application with salicylic acid increased the number of seeds per umbel by $75.62 \%$ (135.51 number) compared to control (77.16 number). The results of this study confirmed that in non-stress conditions, foliar application with methanol and in stress conditions, foliar application with salicylic acid were the most effective treatments. In non-stress treatment (irrigation at $90 \%$ of field capacity), no significant difference was observed between the weight of one thousand seeds in foliar application treatments (Table 4). Salicylic acid application in moderate stress (irrigation at $50 \%$ of field capacity) increased the weight of one thousand seeds by $22.10 \%(5.91 \mathrm{~g})$ compared to the control (non-foliar application) with $4.84 \mathrm{~g}$ and use of salicylic acid in severe stress treatments (irrigation at $20 \%$ of field capacity) increased weight of one thousand seeds by $52.64 \%$ $(4.61 \mathrm{~g})$ compared to the control $(3.02 \mathrm{~g})$. However, methanol treatment significantly increased the weight of one thousand seeds in water deficit stress conditions compared to the control, which was not statistically significant with salicylic acid treatment (Table 5).

The reduction of fennel yield components under water-deficit stress conditions has been confirmed by various researchers (Kouchaki et al. 2006; Askari \& Ehsanzadeh 2015). The main reason for the decrease in the yield components of the fennel due to water deficit stress related to the disturbance of pollination as a result of water shortage during the flowering stage and sterilization of emerging umbels. It seems that the role of methanol is more nutritional (Zbiec et al. 2003; Moghadas et al. 2013) and salicylic acid has an effective role in fennel resistance to water deficit stress (Kabiri et al. 2014). Methanol has an effect on increasing growth by increasing photosynthetic activity, increasing cytokine production and

$\mathrm{T}$ a b 1 e 4

Effect of water deficit stress and natural regulators on plant height, harvest index and essential oil percent of Foeniculum vulgare

\begin{tabular}{|c|l|l|l|c|}
\hline \multicolumn{2}{|c|}{ Treatment } & $\begin{array}{c}\text { Plant height } \\
{[\mathrm{cm}]}\end{array}$ & $\begin{array}{c}\text { Harvest index } \\
{[\%]}\end{array}$ & $\begin{array}{c}\text { Essential oil } \\
{[\%]}\end{array}$ \\
\hline \multirow{3}{*}{ Water deficit stress } & $90 \%$ & $86.14 \pm 5.75^{\mathrm{a}}$ & $18.90 \pm 1.12^{\mathrm{a}}$ & $2.56 \pm 0.05^{\mathrm{c}}$ \\
& $50 \%$ & $64.57 \pm 3.92^{\mathrm{b}}$ & $19.51 \pm 1.67^{\mathrm{a}}$ & $3.13 \pm 0.07^{\mathrm{b}}$ \\
& $20 \%$ & $47.23 \pm 4.84^{\mathrm{c}}$ & $13.24 \pm 0.95^{\mathrm{b}}$ & $3.98 \pm 0.18^{\mathrm{a}}$ \\
\hline \multirow{3}{*}{ Natural regulators } & Control & $60.91 \pm 3.68^{\mathrm{c}}$ & $16.12 \pm 0.26^{\mathrm{b}}$ & $3.18 \pm 0.1^{\mathrm{a}}$ \\
& Spermidine & $62.88 \pm 3.04^{\mathrm{c}}$ & $16.35 \pm 0.95^{\mathrm{b}}$ & $3.22 \pm 0.19^{\mathrm{a}}$ \\
& Salicylic acid & $74.35 \pm 4.11^{\mathrm{a}}$ & $18.73 \pm 1.06^{\mathrm{a}}$ & $3.31 \pm 0.08^{\mathrm{a}}$ \\
& Methanol & $68.02 \pm 2.95^{\mathrm{b}}$ & $17.99 \pm 0.52^{\mathrm{a}}$ & $3.29 \pm 0.12^{\mathrm{a}}$ \\
\hline
\end{tabular}

Means in each column with the same letter are no significant difference $P \leq 0.05$ based on Duncan's multiple range test 
stimulating plant growth, increasing nitrate reductase activity, increasing nitrogen metabolism, and decreasing light respiration, thus improving the fennel yield components (Zbiec et al. 2003; Dorokhov et al. 2015). The reason for the decrease in light respiration in methanol-treated plants is the rapid oxidation of methanol to carbon dioxide and its combination with ribulose $1-5$ bisphosphate carboxylase and reduced oxygen competition (Hossinzadeh et al. 2015). Yield components of cumin increased significantly under drought stress with methanol application but not significantly increased with spermidine application (Nejhad \& Moghaddam 2010). Ramirez et al. (2006) reported that the treatment of tobacco leaves with methanol significantly increased the chlorophyll content of the leaves of this plant. The positive effect of methanol on the growth of various plants under water deficit stress conditions has been confirmed by many researchers (Mirakhori et al. 2009; Moghadas et al. 2013).

\section{Biological yield}

The interaction of water deficit stress and natural regulators significantly affected $(P \leq 0.05)$ the biological yield of the fennel (Table 3). Water deficit stress reduces the turgor pressure, reduces cell growth and plant organ growth (Tardieu et al. 2018). On the other hand, water deficit stress reduces characteristics such as water uptake, nutrients, leaf area, plant growth rate, plant growth period, and these factors ultimately lead to reduced dry matter production (Sah et al. 2014). There was no significant difference between different natural regulators treatments in biological yield in non-water stress treatment (irrigation at $90 \%$ of field capacity). The highest biological yield of the plant $(5,426.92 \mathrm{~kg} / \mathrm{ha})$ was observed in methanol foliar application under nonstress conditions. Salicylic acid treatment at moderate water deficit stress $(4,662.54 \mathrm{~kg} / \mathrm{ha})$ and severe water deficit stress $(3,479.02 \mathrm{~kg} / \mathrm{ha})$ produced the highest biological yield, which no significant difference between foliar application of salicylic acid and methanol under water deficit stress. In moderate and severe stress treatment, foliar application with salicylic acid increased biological yield by $30.27 \%$ and $77.34 \%$, compared to the control treatment, respectively (Figure 1). Methanol increased some of the agronomic characteristics of sugar beet such as

$\mathrm{T}$ a b 1 e 5

Interaction of water deficit stress and natural regulators on uumber of branches per plant, number of umbels per plant, number of seeds per umbel, and weight of one thousand seeds of Foeniculum vulgare

\begin{tabular}{|c|c|c|c|c|c|}
\hline \multicolumn{2}{|c|}{ Treatment } & \multirow{2}{*}{$\begin{array}{c}\text { Number of } \\
\text { branches per plant }\end{array}$} & \multirow{2}{*}{$\begin{array}{c}\text { Number of umbels } \\
\text { per plant }\end{array}$} & \multirow{2}{*}{$\begin{array}{c}\text { Number of seeds } \\
\text { per umbel }\end{array}$} & \multirow{2}{*}{$\begin{array}{c}\text { Weight of one } \\
\text { thousand seeds } \\
{[\mathrm{g}]}\end{array}$} \\
\hline Water deficit stress & Natural regulators & & & & \\
\hline \multirow{4}{*}{$90 \%$} & Control & $14.09 \pm 0.26^{\mathrm{b}}$ & $25.03 \pm 0.76^{\mathrm{b}}$ & $223.95 \pm 8.46^{\mathrm{a}}$ & $5.59 \pm 0.077^{\mathrm{ab}}$ \\
\hline & Spermidine & $13.92 \pm 0.34^{\mathrm{b}}$ & $25.79 \pm 0.84^{b}$ & $224.07 \pm 7.65^{\mathrm{a}}$ & $5.61 \pm 0.073^{\mathrm{ab}}$ \\
\hline & Salicylic acid & $13.78 \pm 0.51^{\mathrm{b}}$ & $26.50 \pm 0.51^{\mathrm{b}}$ & $224.89 \pm 8.02^{\mathrm{a}}$ & $5.85 \pm 0.084^{\mathrm{a}}$ \\
\hline & Methanol & $15.28 \pm 0.56^{\mathrm{a}}$ & $29.67 \pm 1.06^{\mathrm{a}}$ & $245.60 \pm 7.91^{\mathrm{a}}$ & $5.93 \pm 0.095^{\mathrm{a}}$ \\
\hline \multirow{4}{*}{$50 \%$} & Control & $8.22 \pm 0.88^{f}$ & $18.89 \pm 0.62^{\mathrm{e}}$ & $125.15 \pm 6.38^{c}$ & $4.84 \pm 0.054^{\mathrm{c}}$ \\
\hline & Spermidine & $10.21 \pm 0.17^{\mathrm{e}}$ & $19.42 \pm 0.09^{\mathrm{e}}$ & $124.21 \pm 5.29^{c}$ & $5.03 \pm 0.065^{\mathrm{b}}$ \\
\hline & Salicylic acid & $12.09 \pm 0.13^{\mathrm{c}}$ & $23.04 \pm 0.77^{\mathrm{c}}$ & $186.31 \pm 6.25^{\mathrm{b}}$ & $5.91 \pm 0.072^{\mathrm{a}}$ \\
\hline & Methanol & $11.05 \pm 0.09^{\mathrm{d}}$ & $20.52 \pm 0.43^{\mathrm{d}}$ & $166.54 \pm 5.34^{b}$ & $5.78 \pm 0.061^{\mathrm{a}}$ \\
\hline \multirow{4}{*}{$20 \%$} & Control & $4.61 \pm 0.24^{\mathrm{h}}$ & $10.13 \pm 0.25^{\mathrm{h}}$ & $77.16 \pm 4.19^{d}$ & $3.02 \pm 0.035^{\mathrm{d}}$ \\
\hline & Spermidine & $4.59 \pm 0.31^{\mathrm{h}}$ & $10.16 \pm 0.18^{\mathrm{h}}$ & $75.28 \pm 4.41^{\mathrm{d}}$ & $3.35 \pm 0028^{d}$ \\
\hline & Salicylic acid & $8.18 \pm 0.72^{\mathrm{f}}$ & $17.54 \pm 0.34^{\mathrm{f}}$ & $135.51 \pm 6.43^{c}$ & $4.61 \pm 0.047^{\mathrm{c}}$ \\
\hline & Methanol & $5.29 \pm 0.15^{\mathrm{g}}$ & $12.29 \pm 0.26^{\mathrm{g}}$ & $94.10 \pm 3.72^{\mathrm{d}}$ & $4.48 \pm 0.051^{\mathrm{c}}$ \\
\hline
\end{tabular}

Means in each column with the same letter are no significant difference $P \leq 0.05$ based on Duncan's multiple range test 
Biological yield (Nadali et al. 2010). Zbeik et al. (2003) reported that bean, rapeseed, tomato, and sugar beet treated with methanol were less sensitive to water deficiency and produced the same yield as control plants. Salicylic acid improves plant root growth by improving plant photosynthesis under water deficit stress conditions and this increase in the growth of the root system by salicylic acid causes more absorption of water and nutrients, which ultimately leads to an increase in plant biomass (Najmeh et al. 2015; Rizwan et al. 2020).

\section{Seed yield}

The interaction of water deficit stress and natural regulators significantly affected $(P \leq 0.01)$ the seed yield of the fennel (Table 3 ). In water deficit stress treatments, seed yield in all-natural regulators treatments decreased significantly (Figure 2). Mehta et al. (2011) reported that the seed yield of fennel

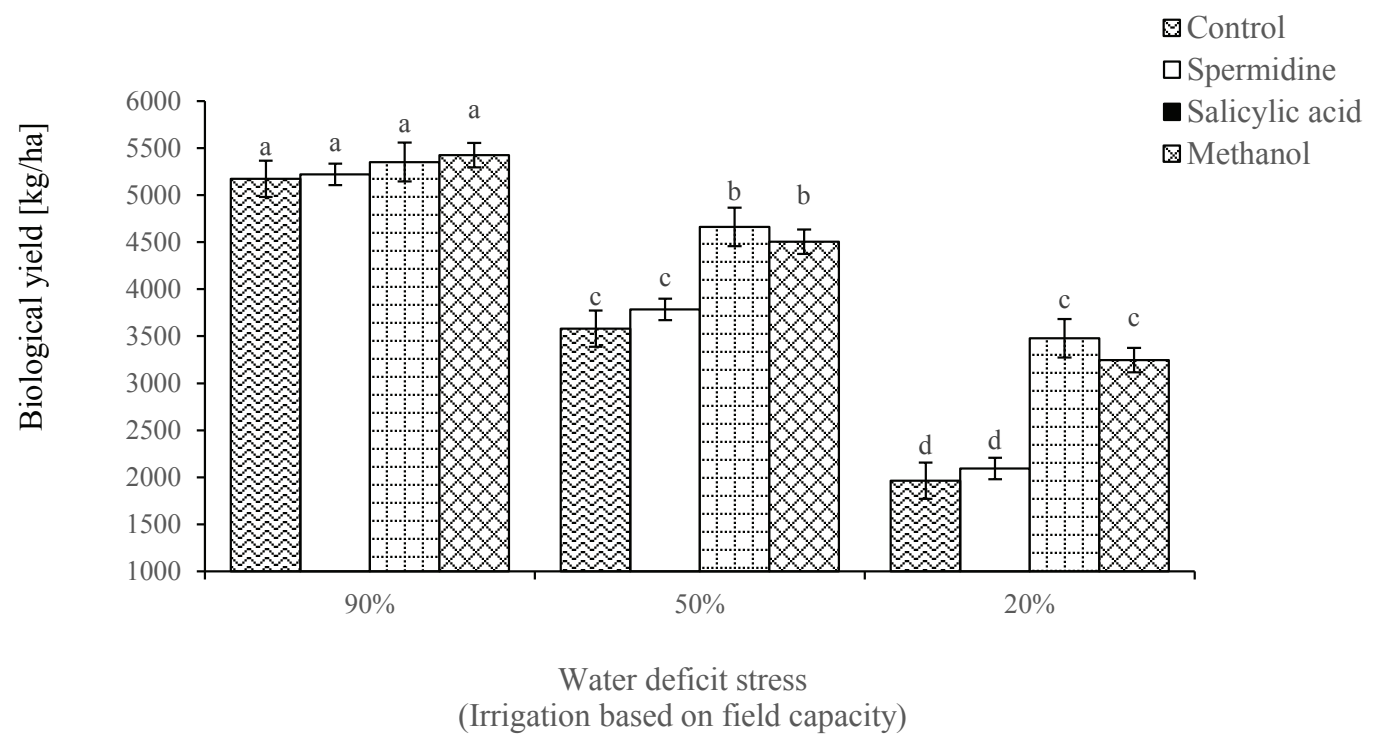

Figure 1. Interaction of water deficit stress and natural regulators on biological yield of Foeniculum vulgare Note: Means with the same letter are no significant difference $P \leq 0.05$ based on Duncan's multiple range test

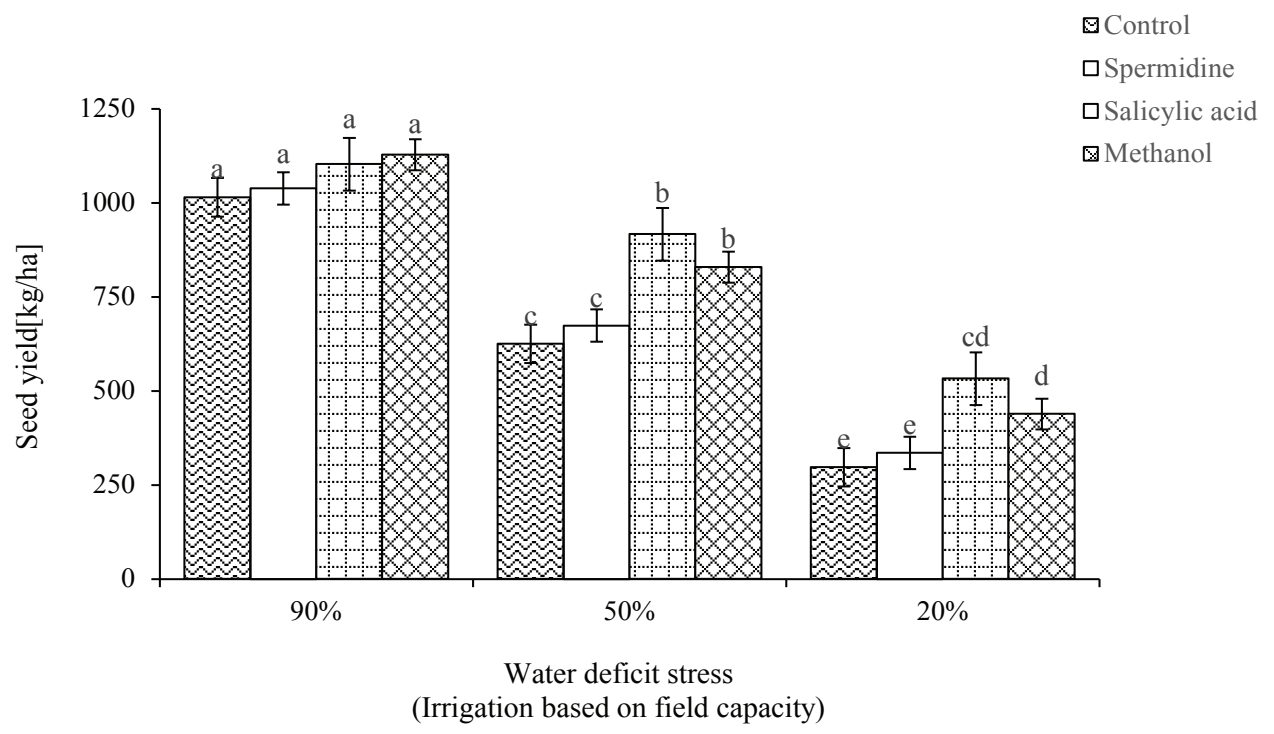

Figure 2. Interaction of water deficit stress and natural regulators on seed yield of Foeniculum vulgare Note: Means with the same letter are no significant difference $P \leq 0.05$ based on Duncan's multiple range test 
at irrigation levels at $75 \%$ and $50 \%$ of field capacity compared to full irrigation decreased by $22.3 \%$ and $51 \%$, respectively. They stated that water deficit stress levels, plant growth parameters decreased and the combination of these factors eventually led to a decrease in fennel seed yield. The use of methanol foliar application treatment under non-water deficit stress conditions and salicylic acid treatment under stress condition significantly improve seed yield (Figure 2).

The highest seed yield $(1,127.59 \mathrm{~kg} / \mathrm{ha})$ belonged to methanol foliar application in the nonstress treatment and the lowest seed yield (297.31 $\mathrm{kg} / \mathrm{ha}$ ) belonged to non-foliar application in severe water deficit stress. Water deficit stress increased the role of salicylic acid in fennel seed yield (Figure 2). Under stress conditions, methanol and salicylic acid application significantly increased seed yield compared to control treatment (non-foliar application) and spermidine application. There was no significant difference between control (non-foliar application) and spermidine foliar application treatments in all water deficit stress treatments. In general, methanol foliar application under non-stress conditions and salicylic acid under stress conditions had the highest seed yield (Figure 2). Bakhtati et al. (2016) showed that seed yield of Cuminum cyminum increased with the application of spermidine under drought stress but the increase in seed yield was not significant compared to the control (no use of spermidine). Salicylic acid significantly increases plant yield and yield components by regulating physiological and biochemical processes during plant growth in the face of biotic and abiotic stresses (Seagate et al. 2020). Salicylic acid accelerates growth improvement after water deficit stress by developing plant resistance to water deficit stress such as increased proline accumulation (Salarpour \& Frahbakhash 2014). Ghilavizadeh et al. (2019) introduced a positive and significant role of salicylic acid foliar application in water deficit stress conditions on fennel seed yield. In many plants, increased seed yield has been reported due to methanol consumption (Faver \& Gerik 2006; Moghadas et al. 2013).

\section{Harvest index}

Fennel harvest index was affected by the simple effects of water deficit stress and natural regulators, but the interaction of these treatments on this trait was not significant (Table 3). The highest harvest index (19.51\%) was observed in the moderate water deficit stress (irrigation treatment of $50 \%$ of field capacity), which did not have a significant difference with the non-water deficit stress condition (18.90\%). The lowest harvest index (13.24\%) was obtained in severe water deficit stress treatment (irrigation at $20 \%$ of field capacity), which had a significant difference between non-water deficit stress and moderate water deficit stress treatments (Table 4).

Water plays an important role in the transfer of materials to the seeds (Roghayyeh et al. 2014). The stress of water shortage during seed filling reduces the transfer of photosynthetic material to the seeds, which leads to a decrease in harvest index (Liu et al. 2017; Ghilavizadeh et al. 2019). Comparison of the mean effect of natural regulators on harvest index showed that the use of salicylic acid, and methanol caused a significant increase in fennel harvest index compared to non-foliar treatment and the application of spermidine was not significantly different from the control. Foliar application of methanol, salicylic acid and spermidine increased the harvest index compared to the control (non-foliar application) by $11.60 \%, 16.19 \%$, and $1.42 \%$, respectively (Table 4).

\section{Essential oil percent}

The percentage of seed essential oil under the water deficit stress was significant at the level of one percent probability (Table 3 ). The percentage of plant essential oil increased significantly with increasing water deficit stress (Table 4). So that, the lowest (2.56\%) and the highest (3.98\%) essential oil percentages were obtained in the treatment of nonstress and severe water deficit stress, respectively. The results of this study show that moderate and severe water deficit stresses increase significant essential oil percent in comparison with the non-stress condition.

With the availability of water and nutrients for the plant, the plant preferentially allocates carbon for growth, but with the reduction of irrigation water, the availability of nutrients is reduced and plant growth is limited more than photosynthesis, as a result, most of the photosynthetic material is allocated to the production of secondary metabolites and es- 
sential oils (Bettaieb et al. 2009; Corell et al. 2012). Essential oils are part of the secondary metabolites in plants and plants increase the amount of these substances in their organs when receiving environmental stress (Diao et al. 2014; Ibrahim et al. 2020). Therefore, in the present experiment, water deficit stress condition increased the secondary metabolites of fennel, including the percentage of essential oil.

\section{Essential oil yield}

Essential oil yield was affected by the interaction effects of water deficit stress and natural regulators at a probability level of 5\% (Table 3). In all foliar application treatments, the essential oil yield decreased with water deficit stress (Figure 3). Under non-water deficit stress conditions, methanol foliar application had the highest essential oil yield (22.67

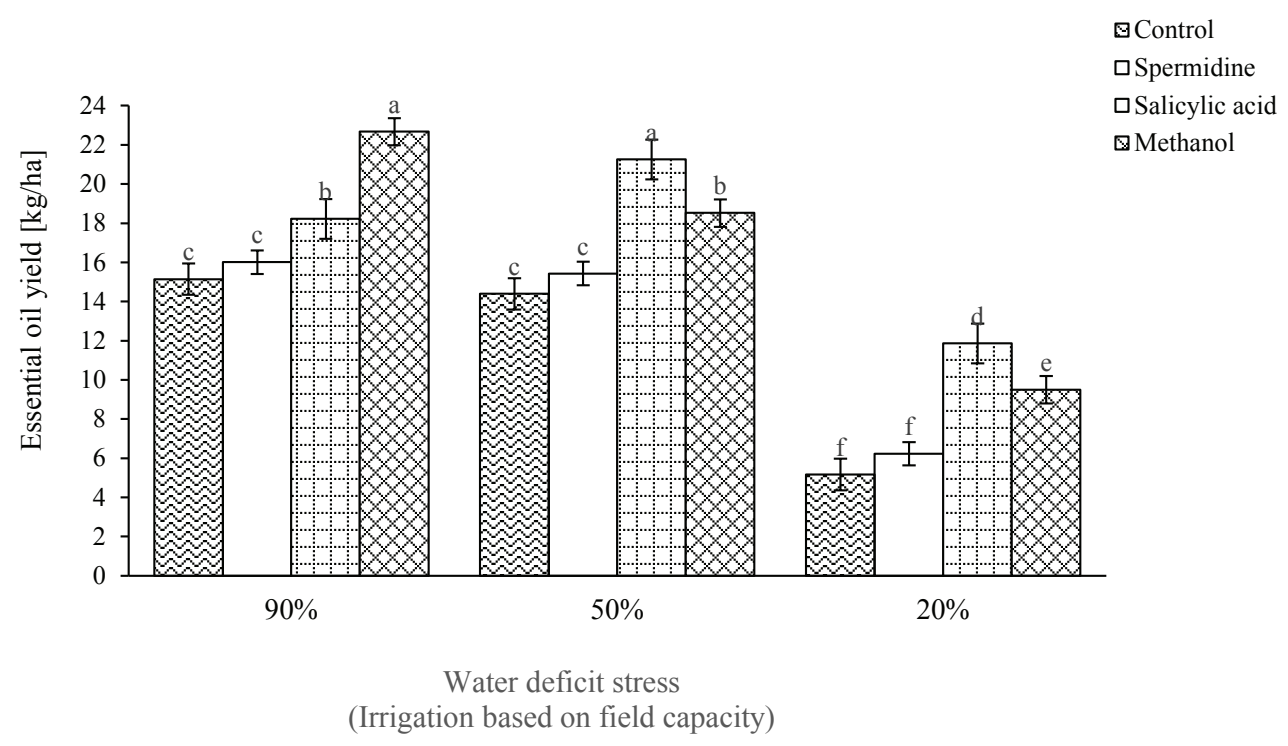

Figure 3. Interaction of water deficit stress and natural regulators on essential oil yield of Foeniculum vulgare Note: Means with the same letter are no significant difference $P \leq 0.05$ based on Duncan's multiple range test

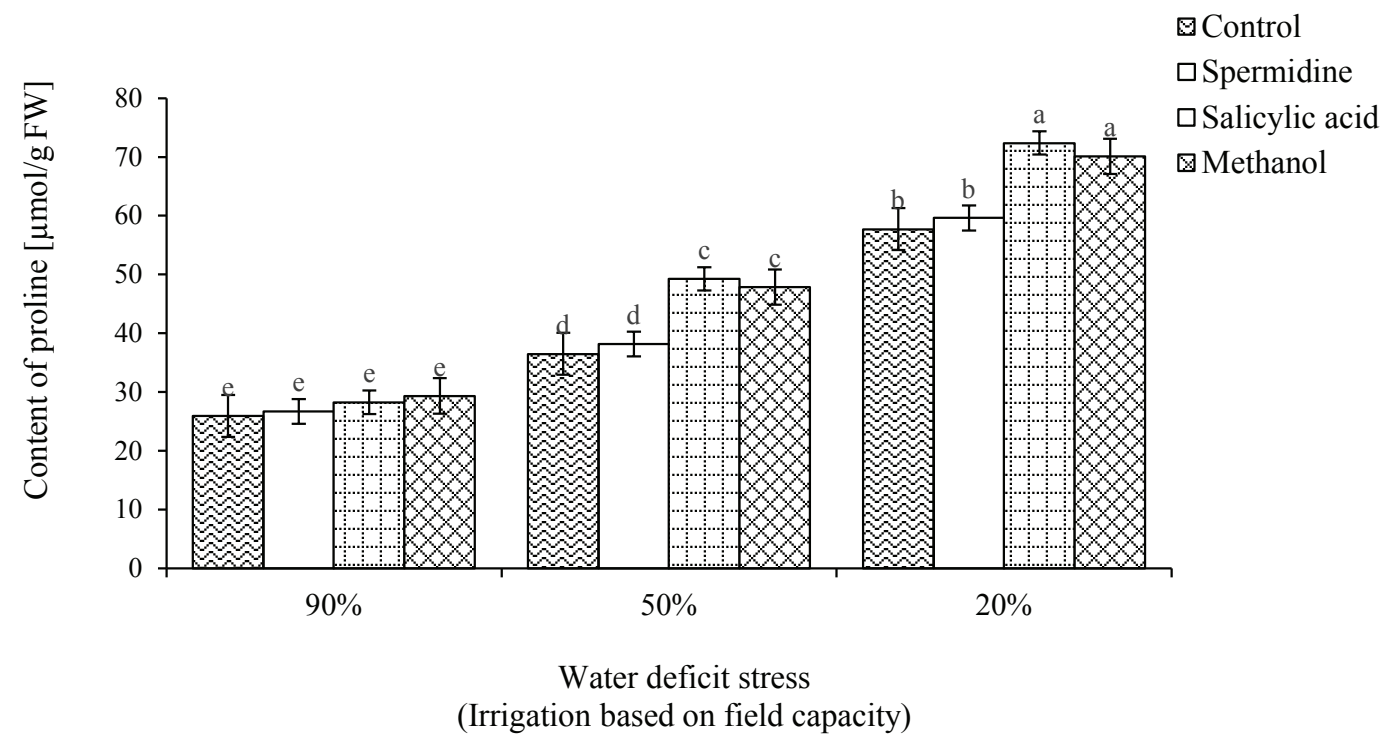

Figure 4. Interaction of water deficit stress and natural regulators on proline content of Foeniculum vulgare Note: Means with the same letter are no significant difference $P \leq 0.05$ based on Duncan's multiple range test 
$\mathrm{kg} / \mathrm{ha}$ ). However, in moderate and severe water deficit stresses, the application of salicylic acid had the highest yield of essential oil with 21.25 and 11.86 $\mathrm{kg} / \mathrm{ha}$, respectively. The essential oil yield of fennel in moderate water deficit stress with the application of salicylic acid was not significantly different in comparison to methanol application with non-stress conditions (Figure 3).

Foliar application of methanol and salicylic acid under water deficit stress had a positive effect on essential oil yield, but the foliar application of salicylic acid performed better than methanol treatment and salicylic acid increased the yield of essential oil by more than 2 times in severe water deficit stresses (irrigation treatment of $50 \%$ of field capacity) in comparison to non-foliar application. In general, methanol foliar application under non-stress conditions and salicylic acid foliar application under water deficit stress conditions are recommended to achieve the highest essential oil yield. Essential oil yield is a result of the percentage of essential oil and seed yield (Diao et al. 2014). So the main reason for the high yield of essential oil in non-water deficit stress conditions and the use of methanol or salicylic acid is the higher seed yield in these treatments.

Although the percentage of essential oil increased in water deficit stress treatments, however, the yield of essential oil decreased due to a significant decrease in seed yield (Bahreininejad et al. 2014). Askari and Ehsanzadeh (2015) in Foeniculum vulgare, Castro et al. (2020) in Lippia alba, and Bettaieb et al. (2009) in Salvia oficinalis reported drought stress significantly reduced essential oil yield.

\section{Proline content}

The interaction of water deficit stress and natural regulators significantly affected $(P \leq 0.05)$ the proline content of the fennel (Table 3 ).

The amount of proline increased significantly in all foliar spraying treatments under water deficit stress conditions (Figure 4). The results confirmed a direct relationship between water shortage stress and increased proline content. Increasing the amount of proline in the cytoplasm of the plant causes osmotic regulation, maintenance of cell turgor pressure, and reduction of cell membrane damage, and also proline is a source of energy, carbon, and nitrogen in plants (Tardieu et al. 2018). Proline prevents damage to the cell structure under water deficit stress (Solanki \& Sarang 2014) and enzymes are protected by this proline mechanism due to their protein structure (Singh et al. 2017). Under nonstress conditions, proline content varied between 25.91 to $29.34 \mu \mathrm{mol} / \mathrm{g}$ of fresh weight and the difference between natural regulators treatments was not significant (Figure 4).

In moderate water deficit stress (irrigation at 50\% of field capacity), proline content in treatments of methanol $(47.85 \mu \mathrm{mol} / \mathrm{g}$ fresh weight $)$ and salicylic acid $(49.27 \mu \mathrm{mol} / \mathrm{g}$ fresh weight) was significantly higher than the control $(36.49 \mu \mathrm{mol} / \mathrm{g}$ fresh weight $)$ and the spermidine $(38.16 \mu \mathrm{mol} / \mathrm{g}$ fresh weight) treatments (Figure 4). In severe water deficit stress (irrigation at $20 \%$ of field capacity), proline content in the control treatment $(57.71 \mu \mathrm{mol} / \mathrm{g}$ fresh weight $)$ was significantly lower than that in salicylic acid (72.38 $\mu \mathrm{mol} / \mathrm{g}$ fresh weight) and methanol (70.09 $\mu \mathrm{mol} / \mathrm{g}$ ) treatments. It has been reported that a positive relationship between plant proline content in water-deficit stress conditions with salicylic acid (Solanki \& Sarang 2014) and methanol (Hossinzadeh et al. 2015). Methanol increased the activity of proline-5-carboxylate synthase (P5CS) by decreasing the $\mathrm{pH}$ in the plant and finally caused the accumulation of proline in the plant (Dorokhov et al. 2015; Hossinzadeh et al. 2015). The role of salicylic acid is approved as a growth regulator in tolerance to water deficit stress (Rizwan et al. 2020).

\section{CONCLUSIONS}

The results showed that the irrigation rate from $90 \%$ of field capacity (non-water deficit stress) to $20 \%$ of field capacity (severe water deficit stress) significantly reduced plant height, yield components, biological yield, seed yield, and essential oil yield. But the percentage of essential oil and the amount of proline increased significantly with water deficit stress. Examination of natural regulators treatments showed that the highest harvest index (18.73\%), essential oil percent (3.31\%), and plant height (74.35 $\mathrm{cm})$ were obtained by foliar application with salicylic acid. Interaction effect of water deficit stress and natural regulators showed that methanol foliar 
application under non-stress condition (irrigation at $90 \%$ of field capacity) had the highest number of branches per plant (15.28), number of umbels per plant (29.67), number of seeds per umbel (245.60), weight of one thousand seeds (5.93 g), biological yield $(5,426.92 \mathrm{~kg} / \mathrm{ha})$, seed yield $(1,127.59 \mathrm{~kg} / \mathrm{ha})$ and essential oil yield $(22.67 \mathrm{~kg} / \mathrm{ha})$. The role of salicylic acid in reducing the negative effect of water deficit stress and improving the measured traits in fennel was significantly greater than the effect of methanol, so in water deficit condition, the highest amount of traits was obtained in foliar application with salicylic acid. According to the results of this study, the foliar application of salicylic acid in the cultivation of fennel under water stress is recommended for farmers.

\section{REFERENCES}

Ahmadian, A., Ghanbari, A. and Siahsar, B. (2011). Effect of drought stress and chemicals and organic fertilizers on yield and yield components of Matricaria chamomilla L. Iranian Journal of Agroecology, 3(1), 383-395.

Ahamadizadeh, M., Valizadeh, M., Shahbazi, H. and Nori, A. (2012). Behaviour of durum wheat genotypes under normal irrigation and drought stress conditions in the greenhouse. African Journal of Biotechnology, 11(8), 1912-1923. DOI: 10.5897/AJB11.2370.

Askari, E. and Ehsanzadeh, P. (2015). Osmoregulation-mediated differential responses of field-grown fennel genotypes to drought. Industrial Crops and Products, 76(1), 494-508. DOI:10.1016/j.indcrop.2015.07.010.

Bakhtati, S., Khajoiinajad, G., Mohamadinajad, G. and Alahmoradi, R. (2016). Investigation of the effect of stopping irrigation during flowering and foliar application of spermidine on some quantitative and qualitative characteristics ecotypes of different cumin (Cuminum cyminum). Journal of Horticultural Science, 30(2), 303-315.

Bates, L.S., Waldern, R.P. and Teare, I.D. (1973). Rapid determination of free proline for water-stress studies. Journal of Plant and Soil, 39, 205-207. DOI:10.1007/BF00018060.

Bettaieb, I., Zakhama, N., Wannes, W.A., Kchouk, M.E. and Marzouk, B. (2009). Water deicit effects on Salvia oficinalis fatty acids and essential oils composition. Journal of Scientia Horticulturae, 120(2), 271-275. DOI:10.1016/j. scienta.2008.10.016.

Castro, K.M.D., Batista, D.S. and Otoni, W.C. (2020). Water deficit modulates growth, morphology, and the essential oil profile in Lippia alba L. (Verbenaceae) grown in vitro. Journal of Plant Cell, Tissue and Organ Culture, 141(1), $55-65$.

Chen, Y., Li, G.X., Yuan, M. and Cui, J.M. (2016). Effect of salicylic acid on the antioxidant system and photosystem II in wheat seedlings. Journal of Biologia Plantarum, 60(1), 139-147. DOI:10.1007/s10535-015-0564-4.

Corell, M., Garcia, M.C., Contreras, J.I., Segura, M.L. and Cermetio, P. (2012). Effect of water stress on Salvia oficinalis L. bioproductivity and its bioelement concentrations. Jour- nal of Communications in Soil Science and Plant Analysis, 43(2), 419-425. DOI:10.1080/00103624.2012.641811.

Diao, W.R., Hua, Q., Zhang, H. and Xu, J.G. (2014). Chemical composition, antibacterial activity and mechanism of action of essential oil from seeds of fennel (Foeniculum vulgare Mill.). Journal of Food Control, 35(1), 109-116. DOI: 10.1016/j.foodcont.2013.06.056.

Dorokhov, Y.L., Shindyapina, A.V., Sheshukova, E.V. and Komarova, T.V. (2015). Metabolic methanol: molecular pathways and physiological roles. Journal of Physiological Reviews, 95(2), 603-644. DOI:10.1152/physrev.00034.2014.

Faver, K.L. and Gerik, T.J. (2006). Foliar-applied methanol effects on cotton (Gossypium hirsutum L.) gas exchange and growth. Journal of Field Crops Research, 47(3), 227-234. DOI:10.1016/0378-4290(96)00024-X.

Ghilavizadeh, R., Masouleh, E.H., Zakerin, H.R., Valadabadi, S.A.R., Sayfzadeh, S. and Yousefi, M. (2019). Influence of salicylic acid on growth, yield and macro-elements absorption of fennel (Foeniculum vulgare Mill.) under water stress. Journal of Medicinal Plants and By-products, 8(1), 67-75. DOI:10.22092/JMPB.2019.119386.

Hossinzadeh, S.R., Salimi, A., Ganjali, A. and Ahmadpour, R. (2015). Effect of methanol application on some biochemical characteristics and antioxidant enzymes activity in chickpea under drought stress. Iranian Journal of Plant Physiology and Biochemistry, 1(1), 16-30.

Ibrahim, M.E., Rabbu, H.S., Motawe, H.M. and Hussein, M.S. (2020). Improved growth, yield of seeds and oil production of fennel (Foeniculum vulgare var. vulgare) plants. Journal of Materials and Environmental Science, 11(7), 1112-1120.

Gee, G.H. and Bauder, J.W. (1986). Particle size analysis. In Klute, A. (Ed.) Methods of Soil Analysis. Part 2, Physical properties. SSSA, Madison, WI., pp. 383-409.

Kabiri, R., Hatami, A. and Naghizadeh, M. (2014). Effect of drought stress and its interaction with salicylic acid on fennel (Foeniculum vulgare Mill.) germination and early seedling growth. Journal of Medicinal Plants and By-products, 3(2), 107-116. DOI:10.22092/JMPB.2014.108722.

Kang, G.Z., Li, G.Z., Liu, G.Q., Xu, W., Peng, X.Q., Wang, C.Y., Zhu, Y.J., and Guo, T.C. (2013). Exogenous salicylic acid enhances wheat drought tolerance by inluence on the expression of genes related to ascorbate-glutathione cycle. Journal of Biologia Plantarum, 57(4), 718-724. DOI: 10.1007/s10535-013-0335-z.

Kouchaki, A., Nasiri, M. and Azizi, K. (2006). Effect of different irrigation intervals and density on yield and yield components of two fennel native populations. Iranian Journal of Agricultural Research, 4(1), 131-140.

Kuo, S. (1996). Phosphorus. In Sparks, D.L. (Ed.) Methods of Soil Analysis. Part 3, Chemical methods. SSSA, Madison, WI., pp. 869-920.

Li, Z., Zhou, H., Peng, Y., Zhang, X., Ma, X., Huang, L. and Yan, Y. (2015). Exogenously applied spermidine improves drought tolerance in creeping bentgrass associated with changes in antioxidant defense, endogenous polyamines and phytohormones. Journal of Plant Growth Regulators, 76(1), 71-82. DOI:10.1007/s10725-014-9978-9.

Liu, Y., Li, P., Xu, G., Xiao, L., Ren, Z.P. and Li, Z.B. (2017). Growth, morphological and physiological responses to drought stress in Bothriochloa ischaemum. Journal of Frontiers in Plant Science, 8(1), 1-14. DOI:10.3389/ fpls.2017.00230.

Loeppert, R.H. and Sparks, D.L. (1996). Carbonate and gypsum. In Sparks, D.L. (Ed.) Methods of Soil Analysis. Part 3, Chemical methods. SSSA, Madison, WI., pp. 437-474.

Mabrouk, B., Kaab, S., Rezgui, M., Majdoub, N., Silva, J.T. and Kaab, L. (2019). Salicylic acid alleviates arsenic and zinc 
toxicity in the process of reserve mobilization in germinating fenugreek (Trigonella foenumgraecum L.) seeds. SouthAfrican Journal of Botany, 124, 235-243. DOI: 10.1016/j. sajb.2019.05.020.

Mehta, R.S., Anwer, M.M. and Aishwath, O.P. (2011). Growth and yield of fennel (Foeniculum vulgare Mill.) as influenced by irrigation, nutrient levels and crop geometry. Journal of Spices and Aromatic Crops, 20(2), 77-80.

Mirakhori, M., Paknejad, F., Moradi, F., Ardakani, M., Zahedi, H. and Nazeri, P. (2009). Effect of drought stress and methanol on yield and yield components of soybean max (L 17). American Journal of Biochemistry and Biotechnology, 5(4), 162-169. DOI:10.3844/ajbbsp.2009.162.169.

Moghadas, S.M.T., Sani, B. and Moaveni, P. (2013). Study of foliar application of methanol on drought stress resistance in barley (Hordeum vulgare L.). International Journal of Farming and Allied Sciences, 2(S2), 1307-1310.

Nadali, A., Paknejad, F., Moradi, F., Wazan, S., Soqani, M. and Pazoki, A. (2010). Effects of methanol spraying on relative water content, chlorophyll content and chlorophyll fluorescence of sugar beet leaves under water stress condition. Journal of Ecophysiology of Crops, 2(1), 27-16.

Najmeh, J., Mousavi, N.S. and Naghizadeh, M. (2015). The effect of drought stress and foliar application by salicylic acid on quantitative and qualitative yield of black cumin in kerman climatic conditions. Journal of Crops Management, 17(3), 827-840.

Nejhad, A.H.S. and Moghaddam, P.R. (2010). Effect of biofertilizers and chemical fertilizers on morphological parameters, yield, yield components and essential oil percentage of cumin (Cuminum cyminum). Journal of Horticultural Science, 24(1), 38-44.

Nelson, D.W. and Sommers, L.E. (1996). Total carbon organic carbon and organic matter. In Sparks, D.L. (Ed.) Methods of Soil Analysis. Part 3, Chemical methods. SSSA, Madison, WI., pp. $961-1011$.

Niakan, M., Sadeghi, S. and Gorbanli, M. (2011). Effect of spermidine, salinity stress on germination percentage, growth parameters, osmotic regulators, sodium and chlorine content of wheat straw. Journal of Plant Science Research, 21(2), 89-78.

Ntanos, D.A. and Koutroubas, S.D. (2002). Dry matter and $\mathrm{N}$ accumulation and translocation for Indica and Japonica rice under Mediterranean conditions. Journal of Field Crops Research, 74(1), 93-101. DOI:10.1016/S03784290(01)00203-9.

Pouryousef, M. (2014). Variation in the essential oil constituents in indigenous populations of Foeniculum vulgare var. vulgare from different locations of Iran. Journal of Essential Oil Research, 26(6), 441-445. DOI: 10.1080/10412905.2014.956188.

Ramirez, I.F., Dorta, V., Espinoza, E., Jimenez, A. and Pen, C.H. (2006). Effects of foliar and root applications of methanol on the growth of Arabidopsis, tobacco and tomato plants. Journal of Plant Growth Regulation, 25(1), 30-44. DOI: 10.1007/s00344-005-0027-9.

Rhoades, J.D. (1996). Salinity Electrical conductivity and total dissolved solids. In Sparks, D.L. (Ed.) Methods of Soil Analysis. Part 3, chemical methods. SSSA, Madison, WI., pp. $417-437$.

Rizwan, M., Qurban, A. and Malik, A. (2020). Effects of drought and salt stress on wheat seedling growth related traits under salicylic acid seed priming. International Journal of Botany Studies, 5(1), 130-136.

Roghayyeh, S., Saeede, R., Omid, A. and Mohammad, S. (2014). The efect of salicylic acid and gibberellin on seed reserve utilization, germination and enzyme activity of sorghum
(Sorghum bicolor L.) seeds under drought stress. Journal of Stress Physiology and Biochemistry, 10(1), 5-13.

Seagate, M., Tahmasebi, Sarvestani, Z. and Sorooshzadeh, A. (2020). Foliar-Applied GR24 and salicylic acid enhanced wheat drought tolerance. Russian Journal of Plant Physiology, 67(4), 733-739. DOI:10.1134/S1021443720040159.

Sah, R.P., Chakraborty, M., Prasad, K. and Pandit, M. (2014). Combining ability and genetic estimates of maize hybrids (Zea mays L.) developed using drought tolerant testers. Maize Journal, 3(1), 9-17.

Salarpour, G.F. and Frahbakhash, H. (2014). Effect of drought stress and salicylic acid on physical and physiological traits of fennel. Journal of Agricultural Crop Management, 16(3), $765-778$.

Salehi, M. (2013). Effect of foliar application of methanol on the growth and yield of soybean. Journal of Environmental Treatment Techniques, 1(2), 122-125.

Shakib, M.F., Naderi, R. and Mashhadi, M. (2013). Effect of spraying on spermidine on morphological, physiological and biochemical characteristics of Iranian cyclamen persicum Miller. Journal of Herbal Ecophysiology Magazine, 5(13), 96-113.

Singh, A., Sharma, M.K. and Sengar, R.S. (2017). Osmolytes: Proline metabolism in plants as sensors of abiotic stress. Journal of Applied and Natural Science, 9(4), 2079-2092. DOI:10.31018/jans.v9i4.1492.

Solanki, J.K. and Sarangi, S.K. (2014). Effect of drought stress on proline accumulation in peanut genotypes. International Journal of Advanced Research, 2(10), 301-309.

Stefanini, M.B., Ming, L.C., Marques, M.O.M., Meireles, M.A.A., Moura, L.S. and Marchese, J.A. (2006). Seed productivity, yield and composition of the essential oil of fennel Foeniculum vulgare var. dulcis in the season of the year. Revista Brasileira de Plantas Medicinais, 8(S), 86-90.

Tardieu, F., Simonneau, T. and Muller, B. (2018). The physiological basis of drought tolerance in crop plants: A scenario-dependent probabilistic approach. Annual Review of Plant Biology, 69, 733-759. DOI:10.1146/annurev-arplant-042817-040218.

Tatrai, Z.A., Sanoubar, R., Pluhar, Z., Mancarella, S., Orsini, F. and Gianquinto, G. (2016). Morphological and physiological plant responses to drought stress in Thymus citriodorus. International Journal of Agronomy, 10(2), 1-8. DOI:10.1155/2016/4165750.

Telci, I., Demirtas, I. and Yaglioglu, A.S. (2009). Variation in plant properties and essential oil composition of sweet fennel (Foeniculum vulgare Mill.) fruits during stages of maturity. Industrial Crops and Products, 30(1), 126-130. DOI: 10.1016/j.indcrop.2009.02.010.

Thomas, G.W. (1996). Soil pH and soil acidity. In Sparks, D.L. (Ed.) Methods of Soil Analysis. Part 3, Chemical methods. SSSA, Madison, WI., pp. 475-491.

Zbiec, I., Karczmarczyk, S. and Podsialo, C. (2003). Response of some cultivated plants to methanol as compared to supplemental irrigation. Electronic Journal of Polish Agricultural Universities, 6(1), 1-7.

Zheng, Y.J., Yang, Y.Q., Liang, S.S. and Yi, X.F. (2008). Effect of methanol on photosynthesis and chloro-phyll fluorescence of flag leaves of winter wheat. Agricultural Sciences in China, 7(4), 432-437. DOI:10.1016/S16712927(08)60086-3.

Received: November 11, 2020 Accepted: April 21, 2021 